\title{
ArcheoSciences
}

Revue d'archéométrie

\section{A particular temper: mineralogical and petrographic characterisation of ceramic fabrics with glauconitic inclusions}

Un dégraissant particulier : caractérisation minéralogique et pétrographique de pâtes céramiques à inclusions glauconitiques

Elena Basso, Claudio Capelli, Maria Pia Riccardi and Roberto Cabella

(2) OpenEdition

Journals

Electronic version

URL: https://journals.openedition.org/archeosciences/1001

DOI: 10.4000/archeosciences. 1001

ISBN: 978-2-7535-1597-0

ISSN: 2104-3728

Publisher

Presses universitaires de Rennes

Printed version

Date of publication: 31 December 2008

Number of pages: 93-97

ISBN: 978-2-7535-0868-2

ISSN: 1960-1360

Electronic reference

Elena Basso, Claudio Capelli, Maria Pia Riccardi and Roberto Cabella, "A particular temper:

mineralogical and petrographic characterisation of ceramic fabrics with glauconitic inclusions",

ArcheoSciences [Online], 32 | 2008, Online since 31 December 2011, connection on 01 February 2022

URL: http://journals.openedition.org/archeosciences/1001 ; DOI: https://doi.org/10.4000/

archeosciences.1001 


\title{
A particular temper: mineralogical and petrographic characterisation of ceramic fabrics with glauconitic inclusions
}

\author{
Un dégraissant particulier : caractérisation minéralogique \\ et pétrographique de pâtes céramiques à inclusions glauconitiques
}

\author{
Elena BASSO*/**, Claudio CAPELli ${ }^{* * *}$, \\ Maria Pia RicCardi*/**** and Roberto Cabella***
}

\begin{abstract}
This paper focuses on the mineralogical and petrographic characterisation of ceramic fabrics rich in glauconitic pellets, found out in a few local productions of European and Mediterranean sites dated from Prehistory to the Middle Ages. The main distinguishing features of glauconitic inclusions are their rounded shape, dark colour and peculiar chemical composition. During the firing - as also evidenced by a few preliminary experimental tests on glauconitic sediments - the pellets change in colour (from green to red or black in thin section) because of the oxidation of divalent iron and their texture becomes more homogeneous, up to the partial or complete vitrification at moderately high temperatures.

Résumé : Dans cet article, on présente la caractérisation minéralogique et pétrographique des pâtes céramiques riches en pellets glauconitiques, trouvées dans quelques productions locales de sites européens et méditerranéens d'age préhistorique à médiéval. Les plus importants éléments discriminants des pellets glauconitiques sont leur forme arrondie, leur couleur rouge ou noire et leur composition chimique particulière. Durant la cuisson, comme quelques tests préliminaires sur sédiments glauconitiques l'ont confirmé, les pellets changent de couleur (de vert à rouge ou noir en lame mince), à cause de l'oxydation du fer bivalent, et leur texture devient plus homogène, jusqu’à la vitrification partielle ou totale à des températures relativement hautes.
\end{abstract}

Key words: Ceramic pastes, Glauconitic pellets, Mineralogical and petrographic analyses.

Mots clés : Analyses minéralogiques et pétrographiques, Pâtes céramiques, Pellets glauconitiques.

\footnotetext{
* Dipartimento di Scienze della Terra - Università degli Studi di Pavia, Via Ferrata 1, 27100 Pavia. (elena.basso@manhattan.unipv.it)(riccardi@ crystal.unipv.it)

** CENISCO - Centro Interdisciplinare per lo Studio e la Conservazione dei Beni Culturali, Dipartimento di Studi Umanistici-Università del Piemonte Orientale "A. Avogadro", Via A. Manzoni 8, 13100 Vercelli

*** Dipartimento per lo Studio del Territorio e delle sue Risorse-Università degli Studi di Genova, Corso Europa 26, 16132 Genova(e-mail: capelli@ dipteris.unige.it)

**** CISRiC - Centro Interdipartimentale di Studi e di Ricerche per la Conservazione dei Beni Culturali - Università degli Studi di Pavia, via Abbiategrasso 207, 27100 Pavia
} 


\section{INTRODUCTION}

Among the various types of raw materials used in the past to produce ceramics, there are the glauconite-rich clays and sands. However, whereas glauconite-rich sediments are fairly diffused, ceramics made of these particular raw materials are little known, at least as for productions with large-scale diffusion.

In our researches, based on thin-section analyses, we found out local productions of ceramics characterised by a temper rich in glauconitic pellets in a few European and Mediterranean sites dated from Prehistory to the Middle Ages (Fig. 1): abri Pendimoun, Castellar (Basso et al., 2006) and Villa Giribaldi, Nice (Binder et al., 1994) in the Maritime Alps, South-Eastern France (Neolithic); Isle of Malta (Bruno \& Capelli, 1999; Roman age); Hérin, Northern France (Roman age, unpublished; we are grateful to R. Clotuche, INRAP, who provided the samples).

In addition, glauconitic fabrics are described in some productions (Fig. 1) of Kent, UK, dated to the Iron age (Castle Hill; Vince, 1996) and the Middle Ages (Cleeve Abbey; Vince, 1998), of North-Western France, dated to the Middle Neolithic (Vivoin; Guesquière et al., 2003) and of Southern France, dated to the Early Neolithic (Alpes Maritimes, Var; Echallier, 1991; Echallier \& Courtin, 1994; Manen et al., 2006).

Glauconite is a Fe-rich dioctahedral mica, with general formula: $\mathrm{K}\left(\mathrm{R}^{3+}{ }_{1.33} \mathrm{R}^{2+}{ }_{0.67}\right)\left(\mathrm{Si}_{3.67} \mathrm{Al}_{0.33}\right) \mathrm{O}_{10}(\mathrm{OH})_{2}$ with $\mathrm{Fe}^{3+}>>$ $\mathrm{Al}$ and $\mathrm{Mg}>\mathrm{Fe}^{2+}$ (Bailey, 1980), that generally occurs in marine sediments (outer-shelf environments characterised

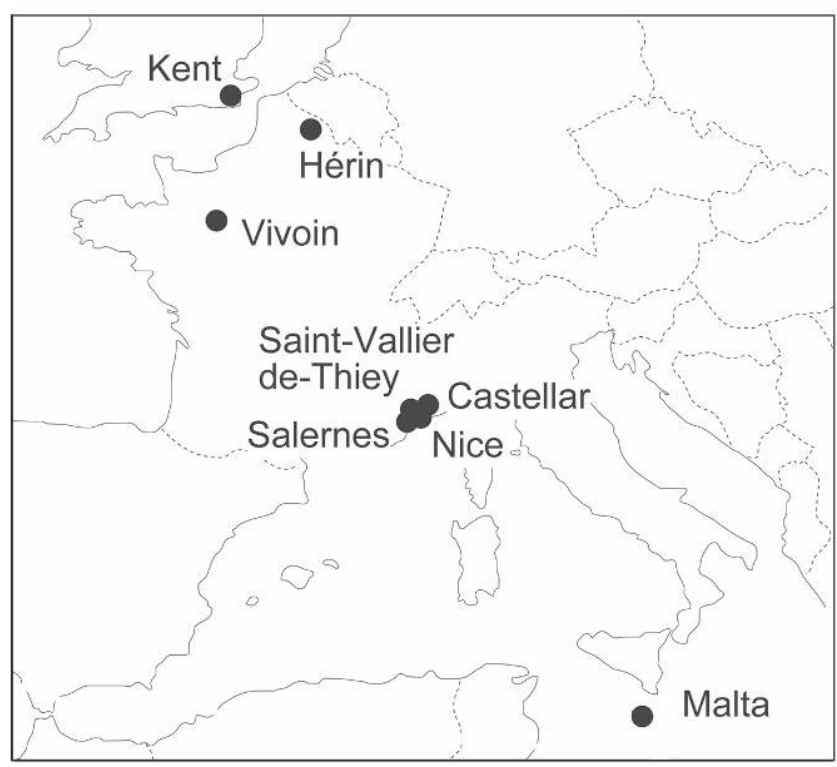

Figure 1: Localisation of the sites discussed in the text. Figure 1: Localisation des sites mentionnés dans le texte. by very slow accumulation rates and moderately reducing conditions), namely in the so-called "green sands". It usually forms, sometimes in association with other phyllosilicates and phosphates, fine-grained rounded aggregates ("pellets"), which are green in colour when observed in thin section (Odin \& Matter, 1981; Deer, Howie \& Zussman, 1992).

It must be noted that green pellets can have a high mineralogical and chemical variability and therefore accurate analyses are necessary in order to discriminate glauconite from celadonite or other phyllosilicate minerals (Bailey, 1980). However, we will use here the term "glauconitic" pellets in a general way.

This paper will focus on the mineralogical and petrographic characterisation (by optical microscopy, XRPD and SEM-EDS) of glauconite-rich ceramic fabrics as well as on the preliminary results of a few experimental firing tests on samples of glauconite-rich sediments, which were carried out in order to highlight the textural and mineralogical changes of glauconitic pellets.

\section{The Distinguishing FEATURES OF GLAUCONITE-RICH FABRICS}

When observed with the naked eye, glauconite-rich fabrics show abundant, well-sorted, spherical or ellipsoidal inclusions, which are black or dark brown in colour.

The dimensions of glauconitic pellets in the studied ceramic pastes range from about 0.25 to $1 \mathrm{~mm}$. The pellets/clay matrix ratio is variable, but textural features (the high sorting) suggest that a glauconitic sand was added to temper a fine-grained clay in most cases.

Under the polarizing microscope, pellets are not pleochroic and their red to black colour depend on firing temperatures and redox conditions. The colour of the inclusions can vary from the core to the surface of the sherd and even differences between core and rim of individual pellets can be observed. The texture of each pellet is generally homogeneous; high-temperature black ones are vitrified and bubblerich (Fig. 2). Fine-grained inclusions of quartz, mica and, most of all, apatite are often recognisable by the scanning electron microscope.

It must be stressed that, in general, X-ray diffractometry was not useful to recognise the presence of glauconite in the ceramic pastes. The lack of characteristic peaks could be explained not only by the strong modifications of glauconite during the firing processes (already at about $375^{\circ} \mathrm{C}$, the oxidation of the divalent iron accompanied by partial loss of hydroxyls takes place; Dekeyser, 1955), but also by the reactions with some associated minerals, which might 

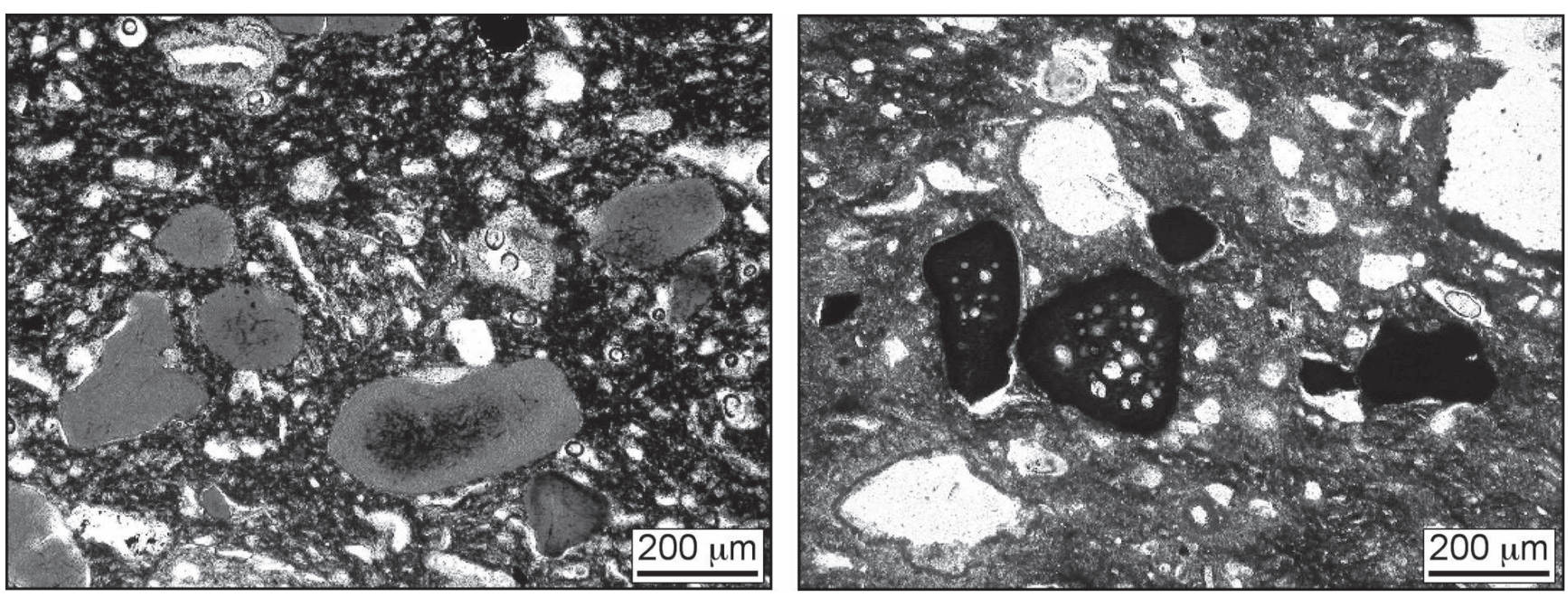

Figure 2 : Thin section examples of glauconitic pellets in ceramic fabrics fired at medium (left) and high (right) temperatures (parallel polars; samples from the Isle of Malta).

Figure 2: Exemples en lame mince de pellets glauconitiques dans des pâtes céramiques cuites à temperatures moyennes (à gauche) et hautes (à droite) (nicols parallèles; échantillons provenant de l'Ile de Malte).

reduce the thermal stability field of glauconite and favour the partial or total vitrification of the pellet.

\section{FIRING TESTS ON GLAUCONITIC SEDIMENTS}

A few experimental pastes were made by mixing 30\% of glauconitic pellets to a clay. Neocomian glauconite-rich layers and marls outcropping at the bottom of the rock shelter covering the Pendimoun site, SE France, were used. The glauconite-rich layers consist of abundant glauconitic pellets included in a very fine-grained matrix. Pellets are spherical or ellipsoidal in shape, with a diameter ranging from 50 to $700 \mu \mathrm{m}$, depending on the position within the sampled layer: the coarser pellets are at the bottom. A green-coloured clayey matrix binds the pellets and the pellets/clay ratio is quite variable. Under the polarising microscope, pellets are inhomogeneous and include apatite grains. They are generally bright green in colour.

Test samples were square-moulded $(4 \times 4 \times 0.5 \mathrm{~cm})$ and fired in a muffle furnace under oxidising atmosphere at maximum $\mathrm{T}=500^{\circ}, 600^{\circ}, 700^{\circ}$ and $800^{\circ} \mathrm{C}$ (kept for 14 hours). The major visible effects of the temperature increase are the change in colour of glauconitic pellets (from green to yellow-orange and then to dark red-brown due to the oxidation of divalent iron) and the progressive homogenisation of their texture (Fig. 3). Further XRD analyses will be carried out in order to focus on the mineralogical changes.

\section{DisCuSSION AND CONCLUSIONS}

Thin section and, only in some difficult cases, SEM-EDS analyses allow us to distinguish, in ceramic pastes, glauconitic inclusions from others that can be quite similar macroscopically, such as Fe-oxides, chamotte, volcanic rock fragments or mafic minerals. Instead, fired glauconite cannot be recognised by XRD analyses.

Colour changes of glauconitic pellets from green to red or black depend on the temperature increase and oxidising conditions inside the kiln.

As in particular for ceramics fired at high temperatures, the loss of optical characteristics due to vitrification processes can make glauconitic pellets look like Fe-oxides/hydroxide nodules, but microchemical analyses show as the former are mainly disinguished by lower $\mathrm{Fe} / \mathrm{Si}$ ratios and major quantities of K (Fig. 4).

With the naked eye, glauconitic fabrics could also be confused with some ceramic pastes rich in volcanic rock and mineral inclusions (augitic clinopyroxene in particular), which are typical of several Roman wine amphorae and coarse wares productions of Central and Southern Italy, largely diffused in the Mediterranean area and in Europe as well (Thierrin-Michael, 1990). However, under the microscope the textural and mineralogical differences are obvious.

In conclusion, ancient European and Mediterranean ceramic productions made from glauconite-rich raw materials are not abundant. Moreover, the diffusion range of these 

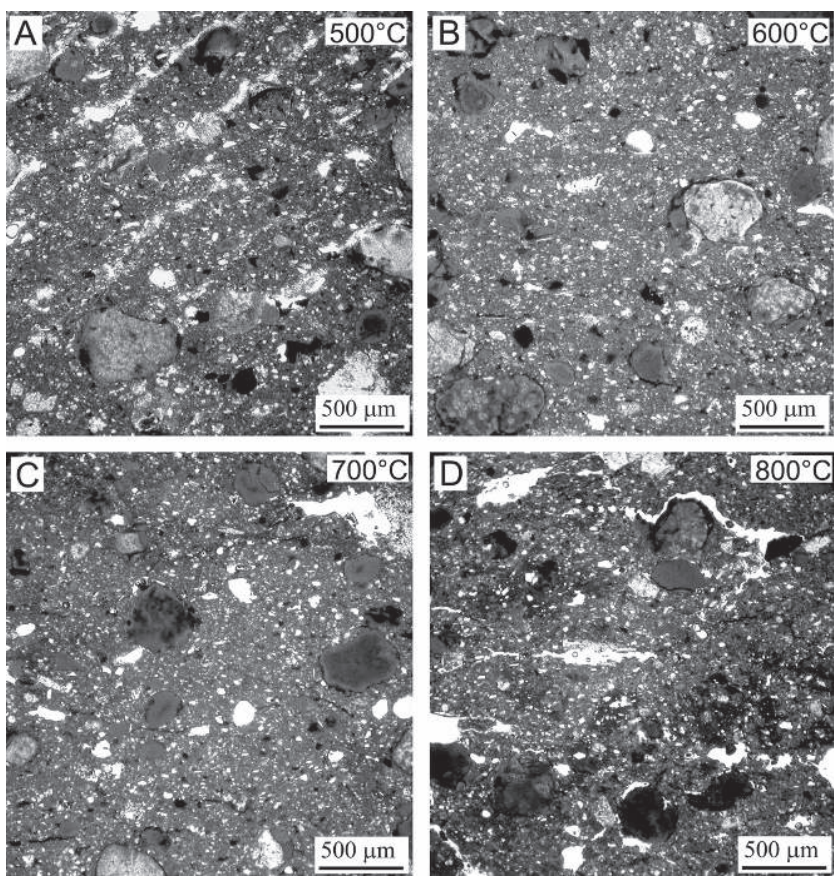

Figure 3 : Particulars in thin section of firing tests on a clay tempered with glauconitic pellets (parallel polars).

Figure 3: Détails en lame mince de tests de cuisson sur une argile mélangée avec un sable glauconitique (nicols parallèles).

productions is quite limited. However, it is important to recognise glauconite temper, in order to avoid misleading archaeological interpretations about production, provenance and trades.

\section{References}

BaILEY, S. W., 1980. Summary of recommendations of AIPEA nomenclature committee on clay minerals. Am. Mineral., 65: $1-7$.

Basso, E., Binder, D., Messiga, B. and Riccardi, M. P., 2006. The Neolithic pottery of abri Pendimoun (Castellar, France): a petro-archaeometric study. In Maggetti, M., Messiga, B. (eds.), Geomaterials in Cultural Heritage. Geological Society, London, Special Publications, 257: 33-48.

BINDER, D., GASSIN, B. and SÉNÉPART, I., 1994. Éléments pour la caractérisation des productions céramiques néolithiques dans le Sud de la France. L'exemple de Giribaldi. In Terre Cuite et Société. La céramique, document technique, économique, culturel. XIV Rencontres Internationales d'Archéologie et d'Histoire d'Antibes, Ed. APDCA, Juan-les-Pins, 255-267.

Bruno, B. and Capelli, C., 1999. Nuovi tipi di anfore da trasporto a Malta. In D'Amico, C. and Tampellini, C. (eds),
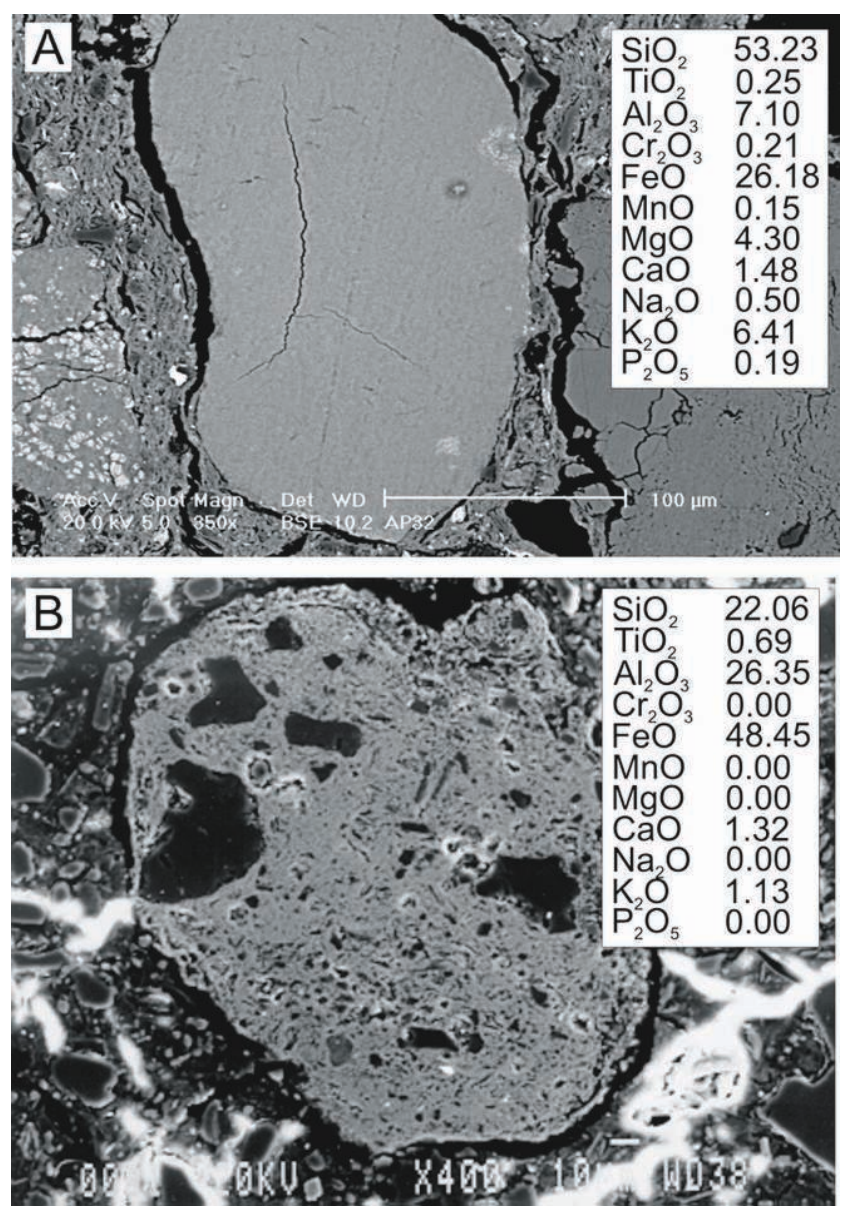

Figure 4 : SEM images and EDS analyses of a glauconitic pellet (top) and a Fe-rich nodule (bottom) included in ceramic fabrics from abri Pendimoun.

Figure 4: Images au MEB et analyses SDE d'un pellet glauconitique (en haut) et d'un nodule riche en fer (en bas) inclus dans des pâtes céramiques provenant de l'abri Pendimoun.

Atti della 6a Giornata: Le Scienze della Terra e l'Archeometria, Grafica Atestina, Este, 59-65.

DeEr, W.A., HowIE, R.A. and Zussman, J., 1992. An introduction to the rock-forming minerals. Longman, London.

DeKeyser, W., 1955. Clay-Mineral Research in Belgium (19451955). Clays and Clay Minerals, 4: 158-160.

Echallier, J.-C., 1991. La céramique. In Binder D. (ed.), Une économie de chasse au Néolihique ancien. La grotte Lombard à Saint-Vallier-de Thiey (Alpes-Maritimes), Monographie du Centre de Recherches Archéologiques, 5, Paris, ed. du CNRS, 71-89.

Echallier, J.-C. and Courtin J., 1994. Approche minéralogique de la poterie du Néolitique ancien de la Baume de Fontbrégoua à Salernes (Var). Gallia Préhistorie, 36: 267-297. 
Guesquière, E., Marcigny, C., Aubry, B., Clément-Sauleau, S., Dietsch-Sellami, M.-F., Deloze, V., Hamon, G., Guerré, G. and Renault, V., 2003. L'habitat néolithique moyen I de Vivoin le Parc (Sarthe). Bulletin de la Société Préhistorique Française, 100, (3): 533-574.

Manen, C., Convertini, F., Binder, D., Beeching, A., Briois, F., Bruxelles, L., Guilaine, J. and Sénépart, I., 2006. Premier résultats du projet ACR "Productions céramiques des premières sociétés paysannes”. L'exemple des faciès impressa du Sud de la France. In Fouéré, P., Chevillot, C., Courtaud, P., Ferullo, O., Leroyer, C. (eds.), Paysages et Peuplements. Aspects culturels et chronologiques en France méridionale. Actualité de la recherche, Actes des Sixièmes Rencontres Méridonales de Préhistoire Récente, Périgueux, 2004, Association pur le Développement de la Recherche Archéologique et Historique en Périgord, Préhistoire du Sud-Ouest, Périgueux, suppl. 11: 233-246.
Odin, G. S. and MatTer, A., 1981. De glauconarium origine. Sedimentology, 28: 611-624.

Thierrin-Michael, G., 1990. Roman wine amphorae: Production sites in Italy and imports to Switzerland. In Pernicka, E., Wagner, G.A. (eds.), Archaeometry 40, Birkhauser Verlag Basel, 523-532.

Vince, A., 1997. Petrological analysis of some Iron Age pottery from Kent, AVAC Reports 1997/007 Lincoln, Alan Vince Archaeology Consultancy. From http://www.postex.demon. co.uk/.

VinCE, A., 1998. The Petrology and ICPS Analysis of the Medieval Floor Tiles from Cleeve Abbey, Somerset. From http://www. postex.demon.co.uk/reports/cleevelframes. htm. 
